\title{
Women's Education: An Important Tool for Birth Reduction? A GMM - Poisson Regression Model Approach
}

\author{
Ali Yedan \\ Economic Commission for Africa, \\ $\mathrm{PhD}$ in economics
}

\begin{abstract}
Burkina Faso is a country with a shallow level of woman's education. However, it is one of the most fertile countries. This paper analyzes whether the education of women reduces the number of births and the Total Fertility Rate in Burkina Faso. It also predicts the average number of births per woman and the Total Fertility Rate if women were better educated. Using data from the Demographic and Health Surveys, I model the two-stage Generalized Method of Moments (GMM) with the Heckman model and Poisson regression. The results show that the high fertility in Burkina Faso is mainly due to the low level of the woman's education. The post-primary education increases the age at first birth. The number of births per woman would be decreased in the quarter and the Total Fertility Rate would pass from 5.4 to 3.6 if all women had at least completed the primary school. If all women had at least an incomplete secondary school, the number of births per woman would halve and the Total Fertility Rate would become 2.0. The government would do better to improve the education system allowing a good education for all, especially for women if it intends to reduce fertility.
\end{abstract}

JEL Classification: C34, C35, I21, I28, J11, J13

Keywords: Educational economics; fertility; Total Fertility Rate; Heckman model; Poisson Regression.

\section{INTRODUCTION}

For centuries, the population growth and fertility issues have been at the center of debates and discussions among economists, demographers, statisticians, specialists, religious, politicians, farmers and ordinary citizens; each analyzing in their way. Moreover, in many of these talks, education is often ignored. Nevertheless, education, as a significant investment in human capital, could be a key factor in fertility issues. This paper tries to analyze the effect of woman's education on fertility in Burkina Faso. In other words, this article examines whether the education of women reduces the number of births per woman and the Total Fertility Rate in Burkina Faso.

These debates on fertility and population growth among economists and demographers have not started now. The most famous known defender of the low population growth was the British economist Thomas Robert Malthus. According to Malthus (1798), "By nature human food increases in a slow arithmetical ratio; man himself increases in a quick geometrical ratio unless want and vice stop him." Thus, he recommends a decline in fertility to avoid future disasters. While Malthusian Theory, being proven false and sharply criticized by multiple economists, nowadays, some Asian countries like China continue to adopt birth control policies and some politicians and specialists believe in the misdeeds of the high population growth.

Otherwise, all birth control policies and public awareness would fail if the population were not enough educated. However, the importance of education is not just about fertility. Education is the foundation for all sustainable development. Also, better education is associated with lower 
mortality, better health, and different migration patterns. Better education also matters for human development, including health, economic growth, and democracy (Wolfgang and Samir, 2011). Already mentioned in the Millennium Development Goals as the second goal "Achieve universal primary education," education for all and girls' education are also mentioned in the Sustainable Development Goals as the fourth goal "Ensure inclusive and equitable quality education and promote lifelong learning opportunities for all." In Burkina Faso, the National Plan for Economic and Social Development - PNDES also mentioned education improvement, as one of its objectives.

The purpose of this paper is to analyze effects of women's education on their fertility in Burkina Faso with adequate econometric methods. Also, this paper examines the effects of education on the age at first birth. In addition, this article predicts the average number of births per woman and the Total Fertility Rate if women were better educated. However, the purpose of this paper is not to underline the benefits of fertility reduction, nor to arbitrate between high and low population growth. This article aims to show the link between fertility and women's education.

To analyze the effects of woman's education on the fertility, the Malaria Indicator Surveys in 2014 (MIS, 2014) of Burkina Faso are used, because they are the most recent data from Demographic and Health Surveys (DHS) Program in Burkina Faso. Since the number of births only takes discrete values, then a count data regression like Poisson Regression should be used. The number of births could depend on the age at first birth (Bongaarts et al., 1984; Kravdal and Rindfuss, 2008). However, including the variable "age at first birth" in the model as such would exclude women who have not yet started their childbearing from the model and would lead to endogeneity of the age at first birth and selection bias estimators. To resolve this problem, two-stage Generalized Method of Moments (GMM) is used. Because of the data selection of the variable "age at first birth", an appropriate econometric model for the regression of the age at first birth is the Heckman's two-step method with a selection of whether births. Thus, the two-stage Generalized Method of Moments (GMM) is used in which in the first stage, the age at first birth is regressed using the two-step Heckman model. In the second stage, the Poisson regression is used for the regression of the number of births.

This paper contributes to the literature on the three points: First, to the best of my knowledge, this article is the first to analyze the link between the woman's education and the fertility in Burkina Faso using recent data. While there are studies that examine the effects of woman's education on the fertility, there is not any study on the topic specifically in Burkina Faso with recent data. This study is very important regarding the various policies and discussions on the reduction of the fertility such as the National Plan for Economic and Social Development PNDES and the meeting of the parliaments on the demographic growth in Burkina Faso. Second, this paper tries to predict the average number of births and the Total Fertility Rate if women in Burkina Faso were more educated. That had never been done in the previous studies, neither in Burkina Faso or elsewhere in the world. Third, the use of Generalized Method of Moments applied to the Poisson regression to determine the effects of education on fertility.

I find that the post primary education of women significantly increases the age at first birth while the primary education doesn't compared to no education. The number of births per woman significantly decreases with women's education from complete primary education. The number of births per woman would be decreased in the quarter if all women had at least completed the primary school and halve if all women had at least an incomplete secondary level. The Total Fertility Rates would be decreased in a third in the first case and almost in two- 
thirds in the second case. The remainder of the paper is organized as follows: the next section explores the literature on the effect of education on fertility. In section 3, I introduce the data and present some descriptive statistics. The econometric models and results are respectively presented in sections 4 and 5. Finally, section 6 concludes this paper.

\section{LITERATURE}

Nowadays, some politicians and specialists believe in the misdeeds of the high population growth. In Burkina Faso, among the defenders of the low population growth, there are the decision-makers of the National Plan for Economic and Social Development (PNDES). According to them, strong demographic growth hampering development progress so the control of annual population growth down from $3.1 \%$ in 2015 to $2.7 \%$ in 2020 is one of the six expected comprehensive outcomes of the PNDES implementation. Also, they aim to reduce total fertility index by 5.4 children per woman in 2015 to 4.7 in 2020 .

All of these population growth and fertility fall policies highlight the demographic dividend. "The demographic dividend is Demographic dividend refers to the growth in an economy that is the resultant effect of a change in the age structure of a country's population. The change in age structure is typically brought on by a decline in fertility and mortality rates."(Investopedia). However, the high population growth has not only disadvantages. It can have notorious advantages. Indeed, according to some economic theories of optimal growth such as models of Solow (1956) inspired by the controversial models of Harrod (1939) and Domar (1947), positive long-term growth is only possible if there is population growth or technical progress. Also, high population growth could lead to strong economic growth in the country and therefore more economic power, which would give the nation more international bargaining power.

The literature on the effect of education on fertility is various. Some authors have focused on a group of countries while others have focused on one country. Singh and Casterline (1985) analyzed the effects of education on fertility in developing countries of various continents. Shapiro (2012), Kravdal (2002), Lloyd et al. (2000) and Ainsworth et al. (1996) interested in Sub-Saharan Africa while Martin and Juarez (1995) and Jain (1981) did the analysis in Latin America. D'Addio and d'Ercole (2005), in turn, focused on OECD countries. Among authors who limited to one country, it could be quoted Kravdal and Rindfuss (2008) in Norway, Rindfuss et al. (1996) in USA, Drèze and Murthi (2001) in India, Goldstein (2011) in Thailand, Pop-Eleches (2010) in Romania, Mosley et al. (1982) in Kenya, Al Riyami et al. (2004) in Oman, Oni (1985) in Nigeria, Sathar (1984) in Pakistan and Axinn and Barber (2001) in Nepal.

Moreover, most authors have limited to descriptive tables and statistics, observations of figures, graphs or linear correlations to check the relation between education and fertility. This analysis does not necessarily explain that the education acts on the fertility; it merely shows that in countries, regions or localities where education is low, fertility is high, or on average women who have a low level of education are those who make more children. However, Ainsworth et al. (1996) and Martin and Juarez (1995) used Ordinary Least Square to check the effect of education on fertility respectively on Sub-Saharan African countries and Latin American countries while Abeynayake et al. (2012) used Multiple Ordinary Least Square regression. Monstad et al. (2008) used Natural Experiment with educational reform as an instrument to control for selection, while Kravdal (2002), Kravdal and Rindfuss (2008) and Axinn and Barber (2001) used Discrete-time hazard regression models.

According to almost all the previous studies, women with higher levels of education have fewer children or the woman's education leads to decrease the fertility. It could be quoted Lloyd et al. 
(2000), Drèze and Murthi (2001), Martin and Juarez (1995), and Mosley et al. (1982). Cochrane (1979) added that urban area education is more likely to relate inversely with fertility than rural area education. He also found that increased education in countries with higher literacy levels is more likely to associate inversely with fertility than in less educated countries. However, Sathar (1984) found that there is only slight differentials were identified between women with no education and those who had primary or less schooling but women with more than primary education had notably lower fertility using Pakistan Fertility Survey 1975. Singh and Casterline (1985) found that in most of Asia countries, only secondary education reduces marital fertility and in Latin America and the Caribbean, any formal education lowers fertility.

While most studies show the inverse relationship between education and fertility, Monstad et al. (2008), by contrast, find no evidence that more education results in more women remaining childless or having fewer children. Furthermore, D'Addio and d'Ercole (2005) show that in the 1990 s, OECD countries where women's education is higher also have higher fertility rates. This paper is an extension in the literature not only by analyzing the effect of women's education on fertility in a country, Burkina Faso, where no specific studies of this kind were conducted, but also, using an appropriate econometric model that no study has used it to my knowledge to link woman's education with fertility.

\section{DATA AND STATISTICS}

\section{Data}

In this paper, I use the Demographic and Health Surveys (DHS) data of Burkina Faso. The Demographic and Health Surveys (DHS) Program has collected, analyzed, and disseminated accurate and representative data on population, health, HIV, and nutrition through more than 300 surveys in over 90 countries and for many years. The DHS Program collects four types of surveys for each country: (i) the Demographic and Health Surveys (DHS), (ii) Service Provision Assessment (SPA) surveys, (iii) the AIDS Indicator Surveys (AIS) and (iv) the Malaria Indicator Surveys (MIS), which are nationally-representative population-based surveys focusing on malaria and related issues usually conducted in a sample of about 3,000 households.

It is this last type of surveys I use in the document, because it is the most recent data from Demographic and Health Surveys (DHS) Program in Burkina Faso. The Burkina Faso MIS, 2014 has collected in all households in the sample, information on women aged $15-49$ and their children under age 5. There are 8111 women aged of 15-49 who have been successfully interviewed. While the object of the Malaria Indicator Surveys (MIS) is to coordinate global efforts to fight malaria, these data include elements that can be used to make other relevant studies.

I use data of individual woman questionnaire from Burkina Faso Malaria Indicator Surveys (MIS), 2014 for three main reasons: (i) They are nationally-representative population-based surveys. (ii) These data include all the information I need mainly information on women's education, births and Socio-demographic characteristics. (iii) These data are the most recent available among all nationally-representative population-based surveys in Burkina Faso.

\section{Variables used}

The analysis being about the effect of the woman's education on her total births, then the dependent variable is the total children ever born. In 2014 in Burkina Faso, the total of children ever born varies from 0 to 18 living births per woman with a maximum of 13 boys and 13 girls. The average number of the births of 15 - 49-year-old women was 3.26 births per woman, that is to say, on average 326 births per 100 women. Remember that these values are not the Total Fertility Rate (TFR). 
The Total Fertility Rate (TFR) is the average number of children a woman would have by the end of her reproductive age if she bore children at the current age-specific fertility rates and is obtained by summing the age-specific fertility rates during the previous five years, or by summing the age-specific fertility rates in the last year and multiplying by five. The Agespecific fertility rates are the number of births per thousand women in the age group during the specified period. The Total Fertility Rate in Burkina Faso in 2014, calculated from AgeSpecific Fertility Rates in the previous five years, was 5.4 children per woman. In the urban areas, this Rate was 3.9 children per woman, while in the rural areas; it was 6.1 children per woman.

One of the interest variables in this study is the age at first birth. While the age at first birth is between 10 and 44-year-old, the average age at first birth is 19.61. The woman's education is also an interesting variable. In 2014 in Burkina Faso, on average, women had less than three years of studies. It is noted that the 49-year-old women, i.e., the women at the end of her reproductive age, have done on average 6.87 births.

In addition to the fertility, the age at first birth and the woman's education, I also use sociodemographic variables in the document. They are the residency area (urban and rural), the region, the religion, the wealth quintile, the current marital statute and the age in 5-years groups. Table A1 in Appendix provides the share of women following the socio-demographic characteristics in addition to their Educational attainment and following their residency areas.

\section{Statistics}

After studying the socio-demographic characteristics of women, I now analyze the average number of children per woman, the Total Fertility Rate (TFR) and the average age at first birth following the educational attainment and the socio-demographic characteristics of women. Table 1 links the fertility of 15 - 49-year-old women, the Total Fertility Rate and the age at first birth with educational attainment.

Table 1: Average number of births per woman, Total Fertility Rate (TFR) and average age at first birth following the educational attainments

\begin{tabular}{|c|c|c|c|}
\hline & $\begin{array}{l}\text { Average number } \\
\text { of births }\end{array}$ & $\begin{array}{c}\text { Total Fertility } \\
\text { Rate }\end{array}$ & $\begin{array}{l}\text { Average Age at } \\
\text { first birth }\end{array}$ \\
\hline No education & $\begin{array}{c}4.10 \\
(2.92)\end{array}$ & 6.0 & $\begin{array}{l}19.15 \\
(3.19)\end{array}$ \\
\hline Incomplete primary & $\begin{array}{l}2.41 \\
(2.54)\end{array}$ & 5.5 & $\begin{array}{l}19.17 \\
(3.31)\end{array}$ \\
\hline Complete primary & $\begin{array}{l}2.29 \\
(2.27)\end{array}$ & 4.8 & $\begin{array}{l}19.49 \\
(3.48)\end{array}$ \\
\hline Incomplete secondary & $\begin{array}{c}0.96 \\
(1.51)\end{array}$ & 3.2 & $\begin{array}{l}20.85 \\
(4.10)\end{array}$ \\
\hline Complete secondary & $\begin{array}{c}1.04 \\
(1.25)\end{array}$ & 2.5 & $\begin{array}{l}23.05 \\
(3.27)\end{array}$ \\
\hline Post-secondary & $\begin{array}{c}0.43 \\
(0.71)\end{array}$ & 1.3 & $\begin{array}{l}25.42 \\
(2.71)\end{array}$ \\
\hline Total & $\begin{array}{c}3.26 \\
(2.93)\end{array}$ & 5.4 & $\begin{array}{l}19.61 \\
(3.54)\end{array}$ \\
\hline Correlation & $-0.2896^{* * *}$ & & $0.2863^{* * *}$ \\
\hline
\end{tabular}

From Table 1, the average number of births of 15 - 49-year-old women with no education is 4.10 births per woman. It is 2.41 and 2.29 births per woman respectively for women with incomplete primary level and complete primary level. The 15 - 49-year-old women with post- 
secondary level have done on average 0.43 birth per woman. Thus, on average, the higher the school attainment of women, the lower the number of births. That is confirmed by a negative and significant correlation between the highest year of education and the number of births even at the 1\% level. Likewise, on average, the higher the school attainment of women, the lower the Total Fertility Rate (TFR). In fact, the Total Fertility Rate (TFR) of women with no education is 6.0 children per woman. It is 5.5 children per woman and 3.2 children per woman respectively for women with incomplete primary level and incomplete secondary level. The TFR is 1.3 for woman while post-secondary level.

Otherwise, on average, the higher the school attainment of women, the higher the age at first birth. While the average age at first birth slightly increases from no education to primary education level (19 year-old), it sharply increases for women with complete secondary (23 year-old) and women with post-secondary level (close to 25.5 year-old). That is confirmed by a positive and significant correlation between the highest year of education and the age at first birth even at the $1 \%$ level. Overall, Table 1 shows that the more educated women begin childbearing later and do fewer children while the less educated women start childbearing early and do more children. It is also showed that the correlation between the age at first birth and the number of births is negative and significant at $5 \%$, i.e., the women, who early give births, do more births compared to the women who give births later.

While the average number of children, the Total Fertility Rate (TFR) and the average age at first birth vary following the education level, they also differ following the socio-demographic characteristics of women from Table A2 in Appendix.

\section{ECONOMETRIC MODEL}

In the previous section, it is shown that on average the number of births decreases when woman's education increases, because, the higher the education level of women, the lower the average number of births and the Total Fertility Rate. However, tables in the previous section do not show that the average decrease in the fertility in the group of educated women is due really to their education level. That could be due to other factors affecting both the education and the fertility like the wealth level. The previous section only suggests that among women more educated, the average number of births and the Total Fertility Rate are low. To check whether the decrease in the fertility is due to the education level or whether the education level affects the fertility, the econometric models that take account of others aspects are required.

\section{Potential determinants of number of births}

The number of children that woman bears could depend on the age she begins childbearing and how long she waits between births. The early births could positively affect the number of births. Therefore, woman's education could change the number of births via the age at first birth. That could also inform that the age at first birth could be a determinant of the number of birth. Thus education could affect fertility through a delayed age at marriage or nuptiality (Singh and Casterline, 1985). The women occupied by education start the fertility later compared to those who drop out school early. In addition, Bongaarts et al. (1984) distinguished two classes of determinants: proximate variables and socioeconomic and environmental variables including woman's education that can affect fertility only indirectly by modifying the proximate determinants including age at marriage. The education could directly affect the fertility. The education of woman could affect the interval of times that she waits between births. 
The death of children is a fundamental determinant. In fact, Drèze and Murthi (2001) find that women's education and child mortality are the most important factors explaining fertility differences across the country and over time. The fact of having children living elsewhere could also affect the number of births. Since the sample is a nationally-representative population of 15 - 49-year-old women, then it includes women of different ages. Ignoring the age of the woman would inevitably lead to a significant omission bias. Thus, the age group of the woman was used as covariates. In the previous section, from Table A2, it is shown that the average number of births and the Total Fertility Rate vary following socio-demographic characteristics like the residency area (urban or rural), region, religion, and wealth quintile. These variables also are used in the model as covariates. In addition to these variables, I use the variable "PSU leave out-means of the dependent variable."

\section{Model description}

The age at first birth may be problematic in the model because this variable is censored for there is no information about the age and first birth of women who have not yet had children. Thus, including the variable as such would exclude women who have not yet started their childbearing from the model. This data selection done by the age at first birth leads to endogeneity of the variable and selection bias estimators. Excluding the variable from the model could lead to an omission bias because the variable is relevant in the model. Faced to this dilemma, two-stage Generalized Method of Moments (GMM) is used in which in the first stage regression of the age at first birth is done. In the second stage, a regression of the number of births is done in replacing the age at first birth by its predict values found in the first stage.

To avoid the problem of identifiability, the age at first birth regression must include at least one covariate that is not among covariates in the regression of the number of births. This variable must be correlated with age at first birth but does not directly determine the number of births. The leave out-means of age at first birth, which is the average age and first birth of other women aged 15 to 49-year-old in the PSU, seems to fulfill this condition. Indeed, the environment or surroundings could influence the behavior of women's fertility. A woman could start her fertility earlier or later depending on whether women in the environment or the surrounding start sooner or later their childbearing. However, there are no direct link between the number of births of a woman and the average age at first birth of other women in the PSU.

Otherwise, because of the data selection of the variable "age at first birth", an appropriate econometric model is the Heckman's two-step method for the regression of the age at first birth with a selection of whether births or not. The selection variable "whether births" which informs whether the woman has ever given births or not is regressed on PSU Leave out-means of "whether births", current marital status and age group. Indeed, in addition to the surrounding captured by the PSU-Leave-out means of "whether births", the marital statute and the age could affect the fact to have at least one birth or not. In fact, it is unlikely for a woman who has never been married or a young girl to have children.

Since the number of births takes discrete values, then a count data regression should be used for the regression of the number of births. Thus, the Poisson regression is used. This Poisson Regression Model was previously used in various studies such as in analysis of patent data (Wang et al., 1998), in demand for medical care (Deb and Trivedi, 2002), in modeling of mortality data from a multi-centre study (Jordan et al., 1997) and in application to models of cigarette smoking behavior (Mullahy, 1997). 
In view of all the information, I propose the following model:

(1) Birth $= \begin{cases}1, & \text { if } \text { Birth }^{*}>0 \\ 0, & \text { if } \text { Birth }^{*} \leq 0\end{cases}$

(2) $E_{c}\left(\right.$ Birth $\left.^{*}\right)=\alpha_{0}+\alpha_{1} \operatorname{LOM}($ Birth $)+\alpha_{2} \operatorname{Single}+\sum_{k=1}^{K_{a}-1} \alpha_{3, k} a g e_{k}$

(3) Age_birth $=\left\{\begin{aligned} \text { Age_birth } & \text { if } \text { Birth }^{*}>0 \\ -, & \text { if } \text { Birth }^{*} \leq 0\end{aligned}\right.$

(4) $E_{C}\left(\right.$ Age_birth $\left.h^{*}\right)=\gamma_{0}+\gamma_{1} L O M\left(A g e_{-} b i r t h\right)+\sum_{k=1}^{K_{e}-1} \gamma_{2, k}$ educ $c_{k}+\sum_{k=1}^{K_{\text {exog } 2}} \gamma_{3, k}$ exog $2_{k}$

(5) $E_{c}\left(N b_{-} b i r t h\right)$

$$
\begin{aligned}
& =\exp \left\{\beta_{0}+\beta_{1} L O M\left(N b_{-} \text {birth }\right)+\beta_{2} \text { Age_birth }+\sum_{k=1}^{K_{e}-1} \beta_{3, k} \text { educ }_{k}\right. \\
& \left.+\sum_{k=1}^{K_{\text {exog } 3}} \beta_{4, k} \text { exog }_{k}\right\}
\end{aligned}
$$

With:

Birth, the dummy variable taking one if the woman has already given birth and 0 else; Age_birth the age at first birth and Nb_birth, the number of births are the dependent variables.

Single is the dummy variable taking one if the woman is never-married and 0 else; age is the 5 -year age group of the woman. educ is the highest educational attainment of the woman. $\operatorname{exog} 2$ is the other exogenous variables in the regression of age at first birth including whether the woman lives in rural areas, her religion, her region and her wealth quintile. exog 3 is the other exogenous variables of the regression of number of births including whether the woman lives in rural areas, her religion, her region and her wealth quintile, her 5-year age group, whether there is equilibrium between the number of sons and daughters, whether there is at least one child elsewhere and whether there is at least one child dead.

$E_{c}($.$) is the conditional first moment; LOM(Birth), the leave out-means of the dependent$ variable and $\exp \{$.$\} is exponential.$

$\alpha, \gamma$. and $\beta$ are parameters and $K_{a}, K_{e}, K_{\text {exog } 2}$, and $K_{\text {exog } 3}$ are respectively the number of groups of the 5-year age groups $\left(K_{a}=7\right)$, the number of highest educational attainment $\left(K_{e}=6\right)$, the number of the exogenous variables of the regression of age at first birth and the number of the exogenous variables of the regression of number of births.

To resolve the model, the two-stage Generalized Method of Moments (GMM) is used in which the two-step Heckman model is used to solve the equations (1) - (4) in the first stage. The Poisson regression is used to resolve the equation (5) in the second stage in which the age at first birth is replaced by its predict values found in the first stage. The estimated coefficients from Poisson regression are the semi-elasticity and are interpreted as the relative change in the dependent variable "the total children ever born" induced by a unit change in the regressor 
$x_{j}$. However, this interpretation is wrong for discrete changes like dummy regressors; then for discrete changes in the expected value, a more accurate estimate is needed (Wooldridge, 2013). For that, the Incidence Rate Ratios are required.

The Incidence Rate Ratios for the Poisson model are obtained by exponentiating the Poisson regression coefficient. A unit change in the regressor $x_{j}$ expected to have a rate exp $\left(x_{j}\right)$ times higher for the dependent variable while holding the other variables constant in the model. However, if $\exp \left(x_{j}\right)$ is less than 1 , a unit changes in the regressor $x_{j}$ expected to decrease the dependent variable by a factor $\exp \left(x_{j}\right)$.

\section{RESULTS}

Before analyzing the effects of woman's education on the number of births, I observe the effects of woman's education on the age at first birth and more generally seek the determinants of the age at first birth.

\section{Effects of woman's education on the age at first birth}

Table A3 in Appendix provides the results of the second step of the Heckman Regression of the age at first birth for the country as a whole (National sample), the urban subsample and the rural subsample. In the models 1 , the various educational attainments as dummy variables are used as covariates while in the models 2, the highest year of education post primary as a continuous variable is used as a covariate for the woman's education.

The models 1 and 2 of Table A3 show that living in rural areas significantly decreases the age at first birth. Thus, seeking the effects on age at first birth separately in rural and urban areas is relevant. Otherwise, the models 2 of Table A3 show that the woman's education leads to an increase in the age at first birth. Given the other variables are held constant in the model, one year of post-primary education leads to a rise in the age at first birth to 0.4 year. Therefore, five years of post-primary education leads to an increase in the age at first birth of about two years. The effect is slightly higher in urban areas and lower in rural areas. In the country as a whole, compared to no education, the primary education (completed or not) does not significantly affect the age at first birth. The post-primary education differently and significantly increases the age at first birth. In fact, compared to no education, the incomplete secondary, the complete secondary level and the post-secondary education increase the beginning of childbearing of respectively $0.8,2.4$ and 3.8 years while holding the other variables in the model constant. These results confirm that the women occupied by the education begin childbearing later.

In the rural areas, only the post-secondary education has a significant rise on the age at first birth. It increases the age at first birth of 3.3 years compared to no education while holding the other variables in the model constant. The incomplete primary education decreases the age at first birth of 0.8 year. We denote that the coefficient of complete secondary is the greatest, but it is not significant. Unlike to rural areas, in the urban areas, all the school levels significantly rise the age at first birth. In fact, in these areas, compared to no education, the incomplete and complete primary education lead to an increase in respectively 1.1 and 2.0 years of the age at first birth. The increase is of 4.4 years for the post secondary education. It is noted that the effect of the incomplete primary is significant only for at $10 \%$ level.

Overall, in the country as a whole and its residency areas, the more the woman's education increases, the more her age at first birth. Regarding to the control variables, in Burkina Faso as a whole and in the rural areas, a low education level, living in rural areas, in some regions and the low wealth quintile negatively affect the age at first birth. In the urban areas, a low education level and living in some region negatively affect the age at first birth. 


\section{Effects of woman's education on the births}

Table 2 provides the Incidence ratio rates, as well adapted for dummy regressors as continuous regressors, of educations on the total children born. The full table (Table A4) is in Appendix.

Table 2: Incidence Rate Ratios for the Poisson model of the total children ever born

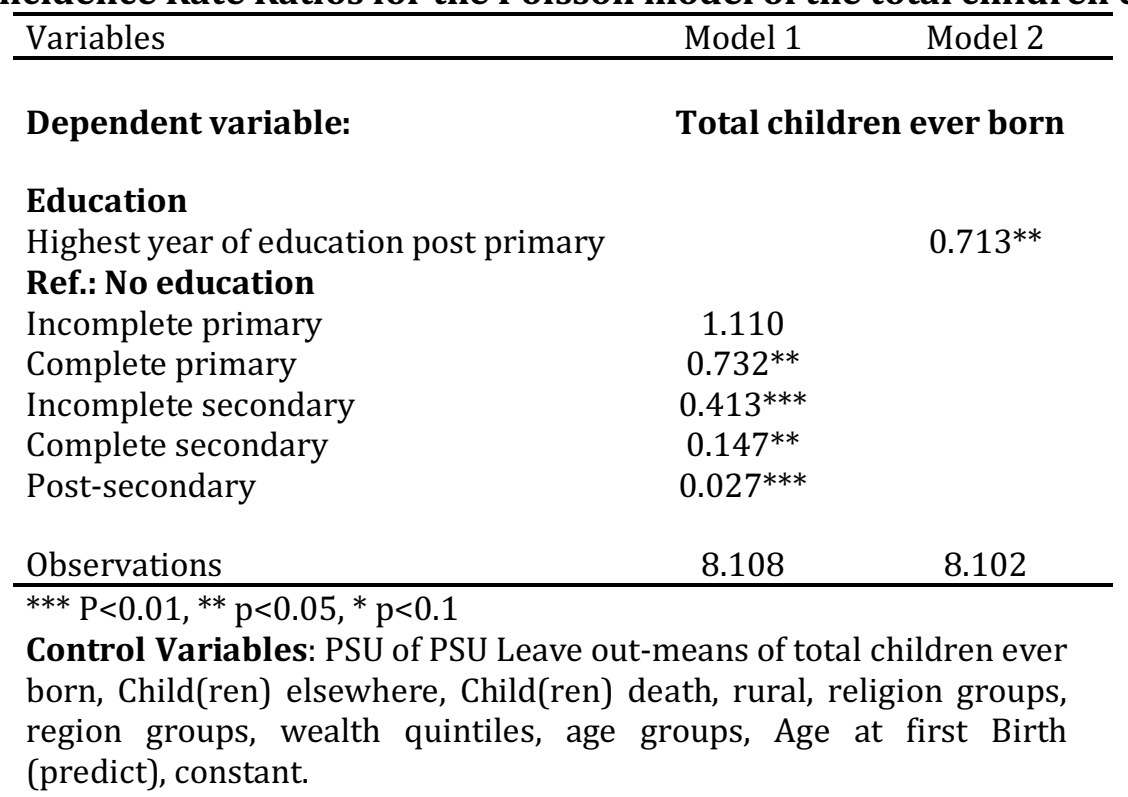

From the model 2, the woman's education leads to a fall in the number of births. Thus, the more, the number of years of post-primary education, the less the woman has many children. The Incidence Rate Ratio is 0.713 , i.e., if a woman were to increase her highest year of postprimary education to one year, her rate ratio for the number of births would be expected to decrease by a factor of 0.713 , while holding all other variables in the model constant. One possible explanation is the knowledge and efficient use of contraceptive methods by the most educated women.

From the model 1, compared to no education, the incomplete primary level does not significantly affect the number of births per woman. However, the other educations levels significantly decrease the woman fertility. Given the other variables are held constant in the model, compared to no education, the complete primary level expects to decrease the number of children by a factor of 0.732 , i.e., leads to a decrease in 1.37 times the number of births. The incomplete secondary level would lead to the decline in more than two times the number of births. Compared to no education, the complete secondary and post-secondary levels expect to decrease the numbers of children respectively by factors of 0.147 and 0.027 . These decreases are very high, that would be due to the low average number of children for women having the complete secondary or post-secondary levels that are respectively 1.04 and 0.43 births per woman.

The estimated coefficients of the predict of age at first birth are not significant even at $10 \%$ level, that means that start earlier or later childbearing do not affect the fertility in Burkina Faso while holding the other variables in the model constant. Therefore, it is thought that women who start earlier childbearing end earlier childbearing and women who begin later childbearing end later: there is a catch-up effect. The negative and significant correlation between the age at first birth and the number of births shows that the negative impact of age at first birth on the number of births is through by other variables in the models especially the woman's education. Thus, in Burkina Faso, the impact of education on fertility is not 
manifested through a delayed age at first birth. Results in Table A4 in Appendix suggest that in addition to the woman's education that highly influences the fertility, the age of the woman, the surrounding, the region, the wealth quintile, having children elsewhere or died are determinants of the number of births.

\section{How would be the average number of births per woman and Total Fertility Rate if women were more educated?}

Table A5 in Appendix provides these results in the country as a whole, only in urban areas and only in urban areas. It also provides the simulation of the average number of births for women aged of 49-year-old. From Table A5, while the national average number of the births of 15 - 49year-old women was 3.3 births per woman, it would be 2.4 births per woman if all women had at least a complete primary school, i.e., a decrease in 0.8 birth per woman or a decrease in 821 births per 1000 women. In rural areas, the average number of the births of 15 - 49-year-old women would pass from 3.8 to 2.8 births per woman, that is to say a decrease in more than a quarter. In urban areas, the decrease in the number of the births of 15 - 49-year-old women would be 957 births per 1000 women passing from 2.1 to 1.1 births per woman, that is to say a decrease in more than $20 \%$ if all women had at least completed the primary school.

Also, Table A5 shows that the national average number of the births of 15 - 49-year-old women would be 1.4 births per woman if all women had at least an incomplete secondary level, i.e. a decrease in 1.8 birth per woman. In rural areas, the average number of the births of 15 - 49-year-old women would pass from 3.8 to 1.6 births per woman, that is to say, a decrease in 58\%. In urban areas, the decrease in the number of the births of 15 - 49-year-old women would be almost in half if all women had at least an incomplete secondary level. When only women at the end of her reproductive age, i.e., the 49-year-old women are focused, the decrease would be almost 2 births per women, with a decrease in $27 \%$ if all women had at least completed the primary school. It would be 4.1 births per women, with a decrease in $58 \%$ if all women had at least an incomplete secondary level.

Like the numbers of births, the Total Fertility Rates would also decrease if women were more educated. In Burkina Faso, in 2014, if all women had at least completed the primary school, the expected average number of children of a woman at the end of her reproductive age if she bore children at the current age-specific fertility rates would be 3.6 children per woman. It would be 2.0 children per woman if all women had at least an incomplete secondary level instead of 5.4. The respective decreases would be 1.8 children per woman and 3.4 children per woman. The Total Fertility Rates would be decreased in a third in the first case and almost in two-thirds $(63 \%)$ in the second case. In the rural areas, the decreases would also be more than a third $(35 \%)$ in the first case and two-thirds in the latter case. The Total Fertility Rate is 6.1 children per woman in the rural areas, but it would be respectively 4.0 children per woman if all women had at least completed the primary school and 2.0 children if all women had at least an incomplete secondary level. In urban areas, the Total Fertility Rates would be 2.8 children per woman, i.e., a decrease in $27 \%$ if all women had at least completed the primary school or 1.8 children per woman, i.e., a decrease in $52 \%$ if all women had at least an incomplete secondary level.

\section{CONCLUSION}

The purpose of this paper is to analyze whether the education of women reduces the number of births per woman and the Total Fertility Rate in Burkina Faso. In addition to providing the effects of woman's education on the age at first birth and on the number of births per woman, this paper predict how the average number of births per woman and the Total Fertility Rate would be if women were better educated. I use the Malaria Indicator Surveys in 2014 (MIS, 
2014) of Burkina Faso being part of Demographic and Health Surveys (DHS) Program. The two-stage Generalized Method of Moments (GMM) is used with two-step Heckman model and the Poisson regression.

I find that the woman's education could affect the age at first birth. However, the primary school level does not significantly affect the age at first birth while the post-primary level leads to an increase in the age at first birth. In rural areas, the education has a significant rise on the age at first birth only for post-secondary level while in the urban areas, all the school levels significantly, positively and differently affect the age at first birth.

Also, the incomplete primary level does not significantly affect the number of births per woman; the other educations levels significantly decrease the woman fertility. The number of birth of a woman would be decreased in $34 \%$ if she were to increase her highest year of education post-primary to one year while holding all other variables in the model constant. The negative effects are greater when the education level is higher. Otherwise, in Burkina Faso, the impact of education on fertility is not manifested through a delayed age at first birth although there is a negative and significant correlation between the age at first birth and the number of births. The results suggest that in addition to the woman's education that highly influences the fertility, the age of the woman, the surrounding, the region, the wealth quintile, having children elsewhere or died are determinants of the number of births.

The number of births per woman would be decreased in the quarter if all women had at least completed the primary school and would halve if all women had at least an incomplete secondary level. The Total Fertility Rates would be decreased in a third in the first case and almost in two-thirds in the second case. The results suggest that the Burkinabe State would do better to improve the national education system allowing a good education for all, especially for all women if it intends to reduce fertility. The State should provide a complete and quality primary education to all women. The focus should be in rural areas because it is the largest part of the country and the least educated. 
Appendix A1

\section{APPENDIX}

Table A1: Some socio-demographic characteristics of women

\begin{tabular}{|c|c|c|c|c|c|c|c|}
\hline Variables & Urban & Rural & National & Variables & Urban & Rural & National \\
\hline \multicolumn{8}{|l|}{$\begin{array}{l}\text { Educational } \\
\text { attainment }\end{array}$} \\
\hline No education & 36.5 & 80.2 & 66.8 & Muslim & 65.9 & 66.2 & 66.1 \\
\hline Incomplete primary & 15.5 & 8.3 & 10.5 & Catholic & 25.8 & 18.6 & 20.8 \\
\hline $\begin{array}{l}\text { Complete primary } \\
\text { Incomplete }\end{array}$ & 6.9 & 3.3 & 4.4 & Protestant & 7.3 & 7.0 & 7.1 \\
\hline secondary & 32.9 & 7.9 & 15.5 & Traditional/Animist & 0.6 & 6.4 & 4.6 \\
\hline Complete secondary & 4.5 & 0.1 & 1.4 & Without religion & 0.4 & 1.8 & 1.4 \\
\hline \multirow[t]{2}{*}{ Post-secondary } & 3.7 & 0.2 & 1.3 & Wealth index & & & \\
\hline & & & & Poorest & 1.3 & 25.6 & 18.1 \\
\hline Milieu & & & & Second & 1.7 & 25.4 & 18.2 \\
\hline Urban & - & - & 30.5 & Middle & 3.9 & 25.7 & 19.0 \\
\hline \multirow[t]{2}{*}{ Rural } & - & - & 69.5 & Fourth & 17.8 & 20.7 & 19.8 \\
\hline & & & & Richest & 75.4 & 2.6 & 24.8 \\
\hline \multicolumn{4}{|l|}{ Region } & $\begin{array}{l}\text { Current marital } \\
\text { status }\end{array}$ & & & \\
\hline Boucle de Mouhoun & 2.7 & 12.3 & 9.4 & Never married & 36.5 & 13.3 & 20.4 \\
\hline Cascades & 2.4 & 3.9 & 3.4 & Married & 59.3 & 84.4 & 76.7 \\
\hline Centre & 46.9 & 2.6 & 16.1 & Widowed & 2.2 & 1.6 & 1.8 \\
\hline Centre-Est & 4.1 & 9.2 & 7.6 & Divorced & 1.9 & 0.8 & 1.2 \\
\hline Centre-Nord & 3.6 & 9.6 & 7.7 & & & & \\
\hline Centre-Ouest & 4.9 & 8.8 & 7.6 & Age in 5-year groups & & & \\
\hline Centre-Sud & 1.2 & 4.7 & 3.6 & $15-19$ & 26.3 & 19.9 & 21.8 \\
\hline Est & 0.8 & 9.3 & 6.7 & $20-24$ & 19.3 & 17.3 & 18.0 \\
\hline Hauts-Bassins & 22.5 & 8.4 & 12.7 & $25-29$ & 18.7 & 17.2 & 17.7 \\
\hline Nord & 5.8 & 8.8 & 7.9 & $30-34$ & 13.4 & 15.1 & 14.6 \\
\hline Plateau Central & 1.3 & 6.3 & 4.8 & $35-39$ & 10.7 & 13.6 & 12.7 \\
\hline Sahel & 2.3 & 11.6 & 8.7 & $40-44$ & 6.7 & 9.6 & 8.7 \\
\hline Sud-Ouest & 1.4 & 4.8 & 3.7 & $45-49$ & 4.8 & 7.3 & 6.5 \\
\hline
\end{tabular}

(Analytic weights assumed) 


\section{Appendix A2}

Table A2: Means of number of children per woman, Total Fertility Rate (TFR) and of age at first birth following of socio-demographic characteristics of women

\begin{tabular}{|c|c|c|c|c|c|c|c|}
\hline & $\begin{array}{l}\text { Mean of } \\
\text { number of } \\
\text { births }\end{array}$ & $\begin{array}{c}\text { Total } \\
\text { Fertility } \\
\text { Rate }\end{array}$ & $\begin{array}{l}\text { Mean of } \\
\text { Age at } \\
\text { first birth }\end{array}$ & & $\begin{array}{l}\text { Mean of } \\
\text { number of } \\
\text { births }\end{array}$ & $\begin{array}{l}\text { Total } \\
\text { Fertility } \\
\text { Rate }\end{array}$ & $\begin{array}{l}\text { Mean of } \\
\text { Age at } \\
\text { first birth }\end{array}$ \\
\hline Milieu & & & & Wealth index & & & \\
\hline Urban & $\begin{array}{c}2.08 \\
(2.32)\end{array}$ & 3.9 & $\begin{array}{l}20.90 \\
(3.69)\end{array}$ & Poorest & $\begin{array}{c}3.96 \\
(3.14)\end{array}$ & 6.4 & $\begin{array}{l}18.86 \\
(3.40)\end{array}$ \\
\hline Rural & $\begin{array}{c}3.78 \\
(3.01)\end{array}$ & 6.1 & $\begin{array}{l}19.00 \\
(3.29)\end{array}$ & Second & $\begin{array}{c}3.84 \\
(3.02)\end{array}$ & 6.3 & $\begin{array}{l}18.58 \\
(2.98)\end{array}$ \\
\hline Region & & & & Middle & $\begin{array}{c}3.76 \\
(2.98)\end{array}$ & 5.9 & $\begin{array}{l}19.21 \\
(3.02)\end{array}$ \\
\hline Boucle de Mouhoun & $\begin{array}{c}3.90 \\
(3.13)\end{array}$ & 6.5 & $\begin{array}{l}19.84 \\
(3.80)\end{array}$ & Fourth & $\begin{array}{c}3.38 \\
(2.84)\end{array}$ & 5.6 & $\begin{array}{l}19.29 \\
(3.47)\end{array}$ \\
\hline Cascades & $\begin{array}{c}3.48 \\
(3.07)\end{array}$ & 5.3 & $\begin{array}{l}18.72 \\
(3.32)\end{array}$ & Richest & $\begin{array}{c}1.85 \\
(2.15)\end{array}$ & 3.5 & $\begin{array}{l}21.40 \\
(3.77)\end{array}$ \\
\hline Centre & $\begin{array}{c}1.90 \\
(2.22)\end{array}$ & 3.4 & $\begin{array}{l}21.34 \\
(3.73)\end{array}$ & Religion & & & \\
\hline Centre-Est & $\begin{array}{c}3.78 \\
(2.89)\end{array}$ & 5.8 & $\begin{array}{l}19.69 \\
(3.00)\end{array}$ & Muslim & $\begin{array}{c}3.31 \\
(2.90)\end{array}$ & 5.6 & $\begin{array}{l}19.39 \\
(3.37)\end{array}$ \\
\hline Centre-Nord & $\begin{array}{c}3.58 \\
(2.87)\end{array}$ & 6.1 & $\begin{array}{l}19.03 \\
(2.74)\end{array}$ & Catholic & $\begin{array}{c}2.90 \\
(2.85)\end{array}$ & 5.0 & $\begin{array}{l}20.44 \\
(3.85)\end{array}$ \\
\hline Centre-Ouest & $\begin{array}{c}3.27 \\
(2.91)\end{array}$ & 5.4 & $\begin{array}{l}19.23 \\
(2.82)\end{array}$ & Protestant & $\begin{array}{c}3.01 \\
(3.02)\end{array}$ & 4.9 & $\begin{array}{l}20.18 \\
(3.51)\end{array}$ \\
\hline Centre-Sud & $\begin{array}{c}3.55 \\
(2.72)\end{array}$ & 5.4 & $\begin{array}{l}19.35 \\
(3.17)\end{array}$ & Traditional/Animist & $\begin{array}{c}4.47 \\
(3.11)\end{array}$ & 6.2 & $\begin{array}{l}18.64 \\
(3.42)\end{array}$ \\
\hline Est & $\begin{array}{c}4.18 \\
(3.40)\end{array}$ & 6.0 & $\begin{array}{l}18.13 \\
(2.97)\end{array}$ & Without religion & $\begin{array}{c}3.67 \\
(2.91)\end{array}$ & 6.3 & $\begin{array}{l}18.15 \\
(3.45)\end{array}$ \\
\hline Hauts-Bassins & $\begin{array}{c}2.93 \\
(2.72)\end{array}$ & 5.1 & $\begin{array}{l}19.09 \\
(3.05)\end{array}$ & Marital status & & & \\
\hline Nord & $\begin{array}{c}3.59 \\
(3.11)\end{array}$ & 5.8 & $\begin{array}{l}19.04 \\
(3.03)\end{array}$ & Never married & $\begin{array}{c}0.16 \\
(0.63)\end{array}$ & 1.0 & $\begin{array}{c}19.75 \\
(3.95)\end{array}$ \\
\hline Plateau Central & $\begin{array}{c}3.22 \\
(2.77)\end{array}$ & 5.6 & $\begin{array}{l}19.63 \\
(3.45)\end{array}$ & Married & $\begin{array}{c}4.04 \\
(2.74)\end{array}$ & 6.3 & $\begin{array}{l}19.62 \\
(3.51)\end{array}$ \\
\hline Sahel & $\begin{array}{c}3.52 \\
(2.90)\end{array}$ & 6.6 & $\begin{array}{l}19.52 \\
(4.32)\end{array}$ & Widowed & $\begin{array}{c}5.61 \\
(2.40)\end{array}$ & 3.9 & $\begin{array}{l}21.32 \\
(4.14)\end{array}$ \\
\hline Sud-Ouest & $\begin{array}{c}3.61 \\
(2.90)\end{array}$ & 5.5 & $\begin{array}{l}19.58 \\
(4.34)\end{array}$ & Divorced & $\begin{array}{c}2.88 \\
(2.65)\end{array}$ & 4.1 & $\begin{array}{l}18.80 \\
(2.93)\end{array}$ \\
\hline Total & $\begin{array}{c}3.26 \\
(2.93)\end{array}$ & 5.4 & $\begin{array}{l}19.61 \\
(3.54)\end{array}$ & Total & $\begin{array}{c}3.26 \\
(2.93)\end{array}$ & 5.4 & $\begin{array}{l}19.61 \\
(3.54)\end{array}$ \\
\hline
\end{tabular}




\section{Appendix A3}

Table A3: Heckman Regression of Age at First Birth

\begin{tabular}{|c|c|c|c|c|c|c|}
\hline \multirow[b]{2}{*}{ VARIABLES } & \multicolumn{2}{|c|}{ National } & \multicolumn{2}{|c|}{ Rural } & \multicolumn{2}{|c|}{ Urban } \\
\hline & Model 1 & Model 2 & Model 1 & Model 2 & Model 1 & Model 2 \\
\hline \multicolumn{7}{|l|}{ Dependent Variable: Age at first birth } \\
\hline PSU Leave out-means of age at first birth & $\begin{array}{c}-0.0109 \\
(0.0575)\end{array}$ & $\begin{array}{c}-0.0119 \\
(0.0577)\end{array}$ & $\begin{array}{c}-0.0624 \\
(0.0638)\end{array}$ & $\begin{array}{c}-0.0529 \\
(0.0636)\end{array}$ & $\begin{array}{c}-0.1150 \\
(0.1226)\end{array}$ & $\begin{array}{c}-0.1303 \\
(0.1260)\end{array}$ \\
\hline \multicolumn{7}{|l|}{ Education } \\
\hline Highest year of education post primary & & $\begin{array}{c}0.4007^{* * *} \\
(0.0564)\end{array}$ & & $\begin{array}{c}0.3285^{* * *} \\
(0.0811)\end{array}$ & & $\begin{array}{c}0.4124^{* * *} \\
(0.0720)\end{array}$ \\
\hline \multicolumn{7}{|l|}{ Ref.: No education } \\
\hline Incomplete primary & $\begin{array}{c}-0.2896 \\
(0.2771)\end{array}$ & & $\begin{array}{c}-0.7579 * * * \\
(0.2631)\end{array}$ & & $\begin{array}{c}1.0987 * \\
(0.6045)\end{array}$ & \\
\hline Complete primary & $\begin{array}{c}0.3752 \\
(0.4084)\end{array}$ & & $\begin{array}{c}-0.3723 \\
(0.4716)\end{array}$ & & $\begin{array}{c}2.0092^{* * * *} \\
(0.6145)\end{array}$ & \\
\hline Incomplete secondary & $\begin{array}{l}0.7923^{* * *} \\
(0.2794)\end{array}$ & & $\begin{array}{c}0.2770 \\
(0.3142)\end{array}$ & & $\begin{array}{c}1.6384^{* * *} \\
(0.4482)\end{array}$ & \\
\hline Complete secondary & $\begin{array}{c}2.3837 * * * \\
(0.8661)\end{array}$ & & $\begin{array}{c}4.2383 \\
(2.8730)\end{array}$ & & $\begin{array}{c}2.6770^{* * *} \\
(0.8712)\end{array}$ & \\
\hline Post-secondary & $\begin{array}{c}3.8008^{* * * *} \\
(0.7115)\end{array}$ & & $\begin{array}{c}3.3402^{* * *} \\
(0.9101)\end{array}$ & & $\begin{array}{c}4.3627 * * * \\
(0.8910)\end{array}$ & \\
\hline \multicolumn{7}{|l|}{ Ref.: Urban } \\
\hline Rural & $\begin{array}{c}-0.5937^{* *} \\
(0.3021)\end{array}$ & $\begin{array}{c}-0.6268^{* *} \\
(0.2998)\end{array}$ & & & & \\
\hline \multicolumn{7}{|l|}{ Religion. Ref.: Animist and other } \\
\hline Muslim & $\begin{array}{c}-0.0019 \\
(0.3689)\end{array}$ & $\begin{array}{c}0.0038 \\
(0.3640)\end{array}$ & $\begin{array}{c}-0.1387 \\
(0.3737)\end{array}$ & $\begin{array}{c}-0.1211 \\
(0.3710)\end{array}$ & $\begin{array}{c}1.1922 \\
(1.3695)\end{array}$ & $\begin{array}{c}1.2422 \\
(1.3709)\end{array}$ \\
\hline Catholic & $\begin{array}{c}0.6417^{*} \\
(0.3876)\end{array}$ & $\begin{array}{c}0.5914 \\
(0.3854)\end{array}$ & $\begin{array}{c}0.6203 \\
(0.3902)\end{array}$ & $\begin{array}{c}0.5443 \\
(0.3897)\end{array}$ & $\begin{array}{c}1.6642 \\
(1.3972)\end{array}$ & $\begin{array}{c}1.7698 \\
(1.4003)\end{array}$ \\
\hline Protestant & $\begin{array}{c}0.1330 \\
(0.4625)\end{array}$ & $\begin{array}{c}0.0396 \\
(0.4485)\end{array}$ & $\begin{array}{c}-0.0898 \\
(0.4571)\end{array}$ & $\begin{array}{c}-0.1720 \\
(0.4515)\end{array}$ & $\begin{array}{c}1.3557 \\
(1.4985)\end{array}$ & $\begin{array}{c}1.3232 \\
(1.4833)\end{array}$ \\
\hline \multicolumn{7}{|l|}{ Region. Ref.: Centre } \\
\hline Boucle de Mouhoun & $\begin{array}{c}0.5325 \\
(0.4833)\end{array}$ & $\begin{array}{c}0.4786 \\
(0.4635)\end{array}$ & $\begin{array}{c}-0.1208 \\
(0.6598)\end{array}$ & $\begin{array}{c}-0.0678 \\
(0.6410)\end{array}$ & $\begin{array}{c}2.1712 \\
(1.4772)\end{array}$ & $\begin{array}{c}1.8174 \\
(1.4635)\end{array}$ \\
\hline Cascades & $\begin{array}{c}-0.4965 \\
(0.4208)\end{array}$ & $\begin{array}{c}-0.5326 \\
(0.4150)\end{array}$ & $\begin{array}{l}-1.0045 \\
(0.6641)\end{array}$ & $\begin{array}{c}-0.9468 \\
(0.6412)\end{array}$ & $\begin{array}{l}-0.2680 \\
(0.6674)\end{array}$ & $\begin{array}{l}-0.4235 \\
(0.7048)\end{array}$ \\
\hline Centre-Est & $\begin{array}{c}0.0896 \\
(0.3991)\end{array}$ & $\begin{array}{c}0.0457 \\
(0.3896)\end{array}$ & $\begin{array}{c}-0.2183 \\
(0.6453)\end{array}$ & $\begin{array}{c}-0.1474 \\
(0.6267)\end{array}$ & $\begin{array}{c}-0.6747 \\
(0.6589)\end{array}$ & $\begin{array}{c}-0.7545 \\
(0.6394)\end{array}$ \\
\hline Centre-Nord & $\begin{array}{c}-0.3341 \\
(0.3911)\end{array}$ & $\begin{array}{c}-0.3786 \\
(0.3878)\end{array}$ & $\begin{array}{c}-0.9882 \\
(0.6359)\end{array}$ & $\begin{array}{c}-0.8966 \\
(0.6171)\end{array}$ & $\begin{array}{c}0.2206 \\
(0.8834)\end{array}$ & $\begin{array}{c}0.0352 \\
(0.7998)\end{array}$ \\
\hline Centre-Ouest & $\begin{array}{c}-0.3938 \\
(0.3858)\end{array}$ & $\begin{array}{c}-0.4793 \\
(0.3786)\end{array}$ & $\begin{array}{c}-0.9304 \\
(0.6412)\end{array}$ & $\begin{array}{c}-0.8118 \\
(0.6319)\end{array}$ & $\begin{array}{c}-0.6681 \\
(0.6281)\end{array}$ & $\begin{array}{c}-0.7638 \\
(0.5464)\end{array}$ \\
\hline Centre-Sud & $\begin{array}{c}0.1871 \\
(0.4575)\end{array}$ & $\begin{array}{c}0.0906 \\
(0.4514)\end{array}$ & $\begin{array}{c}-0.1919 \\
(0.6797)\end{array}$ & $\begin{array}{c}-0.2396 \\
(0.6606)\end{array}$ & $\begin{array}{c}0.0696 \\
(0.9528)\end{array}$ & $\begin{array}{l}-0.2615 \\
(0.9920)\end{array}$ \\
\hline Est & $\begin{array}{l}-0.9140^{*} \\
(0.4695)\end{array}$ & $\begin{array}{c}-0.9573^{* *} \\
(0.4630)\end{array}$ & $\begin{array}{c}-1.4044^{* *} \\
(0.6868)\end{array}$ & $\begin{array}{c}-1.3190^{* *} \\
(0.6687)\end{array}$ & $\begin{array}{l}-1.0559 \\
(1.4675)\end{array}$ & $\begin{array}{c}-0.7649 \\
(1.3940)\end{array}$ \\
\hline Hauts-Bassins & $\begin{array}{c}-0.8443^{* *} \\
(0.4074)\end{array}$ & $\begin{array}{c}-0.8282^{* *} \\
(0.3964)\end{array}$ & $\begin{array}{c}-1.5432^{* *} \\
(0.6576)\end{array}$ & $\begin{array}{c}-1.5326^{* *} \\
(0.6388)\end{array}$ & $\begin{array}{c}-0.3054 \\
(0.5313)\end{array}$ & $\begin{array}{c}-0.5903 \\
(0.5453)\end{array}$ \\
\hline Nord & $\begin{array}{c}-0.2922 \\
(0.4002)\end{array}$ & $\begin{array}{c}-0.3775 \\
(0.3926)\end{array}$ & $\begin{array}{c}-0.8910 \\
(0.6414)\end{array}$ & $\begin{array}{c}-0.8182 \\
(0.6245)\end{array}$ & $\begin{array}{c}0.3453 \\
(0.6935)\end{array}$ & $\begin{array}{l}-0.0826 \\
(0.6912)\end{array}$ \\
\hline Plateau Central & $\begin{array}{c}0.5007 \\
(0.4362)\end{array}$ & $\begin{array}{c}0.4484 \\
(0.4283)\end{array}$ & $\begin{array}{c}-0.1257 \\
(0.6541)\end{array}$ & $\begin{array}{c}-0.0400 \\
(0.6365)\end{array}$ & $\begin{array}{c}1.9605^{*} \\
(1.1155)\end{array}$ & $\begin{array}{c}1.6887 \\
(1.1433)\end{array}$ \\
\hline Sahel & $\begin{array}{c}0.7181 \\
(0.5744)\end{array}$ & $\begin{array}{c}0.6471 \\
(0.5642)\end{array}$ & $\begin{array}{c}0.7104 \\
(0.7743)\end{array}$ & $\begin{array}{c}0.6471 \\
(0.7616)\end{array}$ & $\begin{array}{c}-2.3255^{* *} \\
(1.0655)\end{array}$ & $\begin{array}{c}-2.1006^{* *} \\
(0.9619)\end{array}$ \\
\hline Sud-Ouest & $\begin{array}{c}0.2036 \\
(0.4899)\end{array}$ & $\begin{array}{c}0.1436 \\
(0.4840)\end{array}$ & $\begin{array}{c}-0.0562 \\
(0.7096)\end{array}$ & $\begin{array}{c}-0.1042 \\
(0.6885)\end{array}$ & $\begin{array}{c}-0.4598 \\
(0.8872)\end{array}$ & $\begin{array}{l}-0.5079 \\
(0.8231)\end{array}$ \\
\hline Quintile. Ref.: Poorest & & & & & & \\
\hline Second & $\begin{array}{c}-0.1267 \\
(0.2549)\end{array}$ & $\begin{array}{c}-0.1299 \\
(0.2550)\end{array}$ & $\begin{array}{c}0.0245 \\
(0.2557)\end{array}$ & $\begin{array}{c}-0.0273 \\
(0.2572)\end{array}$ & $\begin{array}{l}-0.3026 \\
(1.8282)\end{array}$ & $\begin{array}{c}-0.2902 \\
(1.6774)\end{array}$ \\
\hline Middle & $\begin{array}{c}0.4413 \\
(0.2976)\end{array}$ & $\begin{array}{c}0.4281 \\
(0.2973)\end{array}$ & $\begin{array}{l}0.7072^{* *} \\
(0.2992)\end{array}$ & $\begin{array}{l}0.6231^{* *} \\
(0.3031)\end{array}$ & $\begin{array}{l}-0.9237 \\
(1.5202)\end{array}$ & $\begin{array}{l}-0.8332 \\
(1.4142)\end{array}$ \\
\hline Fourth & $\begin{array}{c}0.4302 \\
(0.3601)\end{array}$ & $\begin{array}{c}0.3560 \\
(0.3499)\end{array}$ & $\begin{array}{c}0.5042 \\
(0.3929)\end{array}$ & $\begin{array}{c}0.3798 \\
(0.3821)\end{array}$ & $\begin{array}{l}-0.2667 \\
(1.3707)\end{array}$ & $\begin{array}{l}-0.1096 \\
(1.2489)\end{array}$ \\
\hline Richest & $\begin{array}{l}1.7992^{* * *} \\
(0.4548)\end{array}$ & $\begin{array}{c}1.4579 * * * \\
(0.4485)\end{array}$ & $\begin{array}{c}2.5631^{* * *} \\
(0.6369)\end{array}$ & $\begin{array}{c}2.1422^{* * *} \\
(0.6100)\end{array}$ & $\begin{array}{c}0.8725 \\
(1.4076)\end{array}$ & $\begin{array}{c}0.7300 \\
(1.2947)\end{array}$ \\
\hline Constant & $\begin{array}{c}20.2710^{* * *} \\
(1.2972)\end{array}$ & $\begin{array}{c}20.3608^{* * *} \\
(1.3105)\end{array}$ & $\begin{array}{c}21.2140^{* * *} \\
(1.4979)\end{array}$ & $\begin{array}{c}20.9376^{* * *} \\
(1.4797)\end{array}$ & $\begin{array}{c}21.5788^{* * *} \\
(2.8068)\end{array}$ & $\begin{array}{c}22.2906^{* * *} \\
(2.9042)\end{array}$ \\
\hline Observations & 3,344 & 3,343 & 2,407 & 2,406 & 937 & 937 \\
\hline
\end{tabular}

Robust standard errors in parentheses

*** $\mathrm{p}<0.01,{ }^{* *} \mathrm{p}<0.05,{ }^{*} \mathrm{p}<0.1$

Selected by Ever Kids regressed on PSU Leave out-means of Ever Birth, current marital status and age group 


\section{Appendix A4}

Table A4: Incidence Rate Ratios for the Poisson model of the total children ever born

\begin{tabular}{|c|c|c|c|}
\hline Variables & Model 1 & Model 2 & Model 3 \\
\hline Dependent variable: & \multicolumn{2}{|c|}{ Total children ever born } & $\begin{array}{l}\text { Total births in } \\
\text { last five years }\end{array}$ \\
\hline $\begin{array}{l}\text { PSU Leave out-means of dependent variable } \\
\text { Education }\end{array}$ & $1.023^{* *}$ & $1.025^{* *}$ & $1.247^{* * *}$ \\
\hline Highest year of education post primary & & $0.713^{* *}$ & \\
\hline \multicolumn{4}{|l|}{ Ref.: No education } \\
\hline Incomplete primary & 1.110 & & 1.232 \\
\hline Complete primary & $0.732^{* *}$ & & 0.640 \\
\hline Incomplete secondary & $0.413^{* * *}$ & & $0.315^{*}$ \\
\hline Complete secondary & $0.147^{* *}$ & & 0.065 \\
\hline Post-secondary & $0.027^{* * *}$ & & 0.012 \\
\hline \multicolumn{4}{|l|}{ Ref.: No children elsewhere } \\
\hline Child(ren) elsewhere & $1.305^{* * *}$ & $1.304^{* * *}$ & 1.019 \\
\hline \multicolumn{4}{|l|}{ Ref.: No children death } \\
\hline Child(ren) death & $1.428^{* * *}$ & $1.428^{* * *}$ & $1.141^{* * *}$ \\
\hline \multicolumn{4}{|l|}{ Ref.: urban } \\
\hline Rural & $1.417^{*}$ & $1.418^{*}$ & 1.75 \\
\hline \multicolumn{4}{|l|}{ Religion. Ref.: Animist and other } \\
\hline Muslim & 0.996 & 0.993 & 0.993 \\
\hline Catholic & 0.687 & $0.720 *$ & 0.584 \\
\hline Protestant & $0.904^{*}$ & 0.953 & 0.853 \\
\hline \multicolumn{4}{|l|}{ Region. Ref.: Centre } \\
\hline Boucle de Mouhoun & 0.785 & 0.823 & 0.777 \\
\hline Cascades & $1.393^{*}$ & $1.395^{*}$ & 1.732 \\
\hline Centre-Est & 0.976 & 1.004 & 1.063 \\
\hline Centre-Nord & $1.285^{* *}$ & $1.302^{* *}$ & $1.584^{*}$ \\
\hline Centre-Ouest & $1.305^{*}$ & $1.343^{*}$ & 1.552 \\
\hline Centre-Sud & 0.888 & 0.939 & 0.908 \\
\hline Est & $1.898^{* *}$ & $1.884^{* *}$ & 2.44 \\
\hline Hauts-Bassins & $1.689 *$ & $1.618^{*}$ & 2.393 \\
\hline Nord & $1.244^{* *}$ & $1.290^{* *}$ & $1.543^{*}$ \\
\hline Plateau Central & 0.781 & 0.822 & 0.714 \\
\hline Sahel & 0.725 & 0.776 & 0.638 \\
\hline Sud-Ouest & $0.864^{*}$ & $0.896^{*}$ & 0.911 \\
\hline \multicolumn{4}{|l|}{ Quintile. Ref.: poorest } \\
\hline Second & 1.065 & 1.060 & 1.112 \\
\hline Middle & $0.768 *$ & $0.785^{*}$ & 0.656 \\
\hline Fourth & $0.756^{*}$ & $0.795^{*}$ & 0.659 \\
\hline Richest & $0.300^{*}$ & $0.383^{* *}$ & 0.173 \\
\hline \multicolumn{4}{|l|}{ Age group. Ref.: 15 - 19-year-old } \\
\hline $20-24$-year-old & $4.846^{* * *}$ & $5.048^{* * *}$ & $3.956^{* * *}$ \\
\hline 25 - 29-year-old & $8.165^{* * *}$ & $8.556^{* * *}$ & $4.323^{* * *}$ \\
\hline 30 - 34-year-old & $10.503^{* * *}$ & $11.014^{* * *}$ & $3.852^{* * *}$ \\
\hline 35 - 39-year-old & $12.201^{* * *}$ & $12.836^{* * *}$ & $2.939^{* * *}$ \\
\hline 40 - 44-year-old & $13.146^{* * *}$ & $13.879 * * *$ & $1.663^{* * *}$ \\
\hline 45 - 49-year-old & $13.216^{* * *}$ & $13.954 * * *$ & $0.58 * * *$ \\
\hline Age at first Birth (predict) & 1.769 & 1.702 & 2.427 \\
\hline Constant & $0.000^{*}$ & $0.000^{*}$ & 0.000 \\
\hline Observations & 8.108 & 8.102 & 8.108 \\
\hline
\end{tabular}

${ }^{* * *} \mathrm{P}<0.01,{ }^{* *} \mathrm{p}<0.05,{ }^{*} \mathrm{p}<0.1$ 


\section{Appendix A5}

Table A5: Predictions of the average number of births and the Total Fertility Rate if women were more educated

\begin{tabular}{|c|c|c|c|c|c|c|c|c|c|}
\hline & \multicolumn{3}{|c|}{ All Women } & \multicolumn{3}{|c|}{ Women aged of 49-year-old } & \multicolumn{3}{|c|}{ All Women } \\
\hline & $\begin{array}{c}\text { Mean of } \\
\text { total } \\
\text { births }\end{array}$ & $\begin{array}{l}\text { Mean of } \\
\text { decrease }\end{array}$ & $\begin{array}{l}\% \text { of the } \\
\text { decrease }\end{array}$ & $\begin{array}{c}\text { Mean of } \\
\text { total } \\
\text { births }\end{array}$ & $\begin{array}{l}\text { Mean of } \\
\text { decrease }\end{array}$ & $\begin{array}{l}\% \text { of the } \\
\text { decrease }\end{array}$ & TFR & $\begin{array}{l}\text { Decrease } \\
\text { in TFR }\end{array}$ & $\begin{array}{l}\% \text { of the } \\
\text { decrease }\end{array}$ \\
\hline \multicolumn{10}{|l|}{ National } \\
\hline Theoretical mean & 3.262 & & & 6.873 & & & 5.4 & & \\
\hline Empirical mean & 3.257 & & & 7.093 & & & 5.4 & & \\
\hline $\begin{array}{l}\text { Min Education: complete } \\
\text { primary }\end{array}$ & 2.436 & 0.821 & $25 \%$ & 5.178 & 1.915 & $27 \%$ & 3.6 & 1.8 & $33 \%$ \\
\hline $\begin{array}{l}\text { Min Education: incomplete } \\
\text { secondary }\end{array}$ & 1.447 & 1.810 & $56 \%$ & 2.963 & 4.130 & $58 \%$ & 2.0 & 3.4 & $63 \%$ \\
\hline \multicolumn{10}{|l|}{ Rural } \\
\hline Theoretical mean & 3.780 & & & 7.150 & & & 6.1 & & \\
\hline Empirical mean & 3.787 & & & 7.418 & & & 6.1 & & \\
\hline $\begin{array}{l}\text { Min Education: complete } \\
\text { primary }\end{array}$ & 2.794 & 0.993 & $26 \%$ & 5.428 & 1.990 & $27 \%$ & 4.0 & 2.1 & $35 \%$ \\
\hline $\begin{array}{l}\text { Min Education: incomplete } \\
\text { secondary }\end{array}$ & 1.603 & 2.184 & $58 \%$ & 3.113 & 4.305 & $58 \%$ & 2.0 & 4.0 & $66 \%$ \\
\hline \multicolumn{10}{|l|}{ Urban } \\
\hline Theoretical mean & 2.085 & & & 5.534 & & & 3.9 & & \\
\hline Empirical mean & 2.050 & & & 5.526 & & & 3.8 & & \\
\hline $\begin{array}{l}\text { Min Education: complete } \\
\text { primary }\end{array}$ & 1.623 & 0.427 & $21 \%$ & 3.974 & 1.552 & $28 \%$ & 2.8 & 1.0 & $27 \%$ \\
\hline $\begin{array}{l}\text { Min Education: incomplete } \\
\text { secondary }\end{array}$ & 1.093 & 0.957 & $47 \%$ & 2.241 & 3.285 & $59 \%$ & 1.8 & 2.0 & $52 \%$ \\
\hline
\end{tabular}

\section{References}

ABEYNAYAKE Pamudi, BOMHOFF Eduard J., LEE Grace, 2012, "Female age at first marriage and fertility levels: A comparison of developed and developing countries", In: Proceedings of 19th International Business Research Conference.

AINSWORTH Martha, BEEGLE Kathleen, NYAMETE Andrew, 1996, "The impact of women's schooling on fertility and contraceptive use: A study of fourteen sub-Saharan African countries", The World Bank Economic Review, vol. 10, no 1, p. 85-122.

AL RIYAMI Asya, AFIFI Mustafa, MABRY Ruth M, 2004, "Women's autonomy, education and employment in Oman and their influence on contraceptive use", Reproductive health matters, vol. 12, no 23, p. 144-154.

ANGRIST Joshua D, 2014, "The perils of peer effects", Labour Economics, vol. 30, p. 98-108.

AXINN William G., BARBER Jennifer S, 2001, "Mass education and fertility transition", American Sociological Review, vol. 66, no 4, p. 481-505.

BONGAARTS John, FRANK Odile, LESTHAEGHE Ron, 1984, "The proximate determinants of fertility in subSaharan Africa", Population and Development Review, p. 511-537.

CAMERON A. Colin, TRIVEDI Pravin K, 2005, Microeconometrics: methods and applications. Cambridge university press.

COCHRANE Susan Hill, 1979, Fertility and education: What do we really know?

D'ADDIO Anna Christina, D'ERCOLE Marco Mira, 2005, Trends and Determinants of Fertility Rates.

DEB Partha, TRIVEDI Pravin K, 2002, "The structure of demand for health care: latent class versus two-part models", Journal of health economics, vol. 21, no 4, p. 601-625.

Domar Evsey D, 1947, “Expansion and employment”, The American Economic Review, 37(1), pp.34-55.

DRÈZE Jean, MURTHI Mamta, 2001, “Fertility, education, and development: evidence from India”, Population and development Review, vol. 27, no 1, p. 33-63.

GOLDSTEIN Sidney, 1972, "The influence of labour force participation and education on fertility in Thailand", Population Studies, vol. 26, no 3, p. 419-436. 
Yedan, A. (2020). Women's Education: An Important Tool for Birth Reduction? A GMM - Poisson Regression Model Approach. Advances in Social Sciences Research Journal, 7(1) 285-302.

HARROD Roy F, 1939, “An essay in dynamic theory”, The economic journal, vol. 49, no 193, p. 14-33.

Investopedia, Demographic Dividend, reviewed by Will Kenton, updated Nov 7, 2017, https://www.investopedia.com/terms/d/demographic-dividend.asp\#ixzz53tK1rtJh

JAIN Anrudh K, 1981, “The effect of female education on fertility: A simple explanation”, Demography, vol. 18, no 4, p. 577-595.

JORDAN Paul, BRUBACHER Dorothee, TSUGANE Shoichiro, 1997, “Modelling of mortality data from a multi-centre study in Japan by means of Poisson regression with error in variables", International journal of epidemiology, vol. 26, no 3, p. 501-507.

KRAVDAL Øystein, 2002, "Education and fertility in sub-Saharan Africa: Individual and community effects", Demography, vol. 39, no 2, p. 233-250.

KRAVDAL Øystein, RINDFUSS Ronald R, 2008, “Changing relationships between education and fertility: A study of women and men born 1940 to 1964", American Sociological Review, vol. 73, no 5, p. 854-873.

LLOYD Cynthia B., KAUFMAN Carol E., HEWETT Paul, 2000, “The spread of primary schooling in sub-Saharan Africa: Implications for fertility change", Population and development review, vol. 26, no 3, p. 483-515.

LUTZ Wolfgang, SAMIR K. C, 2011, “Global human capital: Integrating education and population”. Science, vol. 333, no 6042 , p. 587-592.

MALTHUS Thomas Robert, 1817, An essay on the principle of population, as it affects the future improvement of society. With remarks on the speculations of Mr. Godwin, m. Condorcet, and other writers. By TR Malthus.

MARTIN Teresa Castro, JUAREZ Fatima, 1995, "The impact of women's education on fertility in Latin America: searching for explanations", International Family Planning Perspectives, p. 52-80.

MONSTAD Karin, PROPPER Carol, SALVANES Kjell G, 2008, “Education and fertility: Evidence from a natural experiment”. Scandinavian Journal of Economics, vol. 110, no 4, p. 827-852.

MOSLEY Wiley Henry, WERNER Linda H., BECKER Stan, 1982, The dynamics of birth spacing and marital fertility in Kenya.

MULLAHY John, 1997, "Instrumental-variable estimation of count data models: Applications to models of cigarette smoking behavior", Review of Economics and Statistics, vol. 79, no 4, p. 586-593.

ONI Gbolahan A, 1985, "Effects of women's education on postpartum practices and fertility in urban Nigeria", Studies in Family Planning, vol. 6, no 6, p. 321-331.

POP-ELECHES Cristian, 2010, "The supply of birth control methods, education, and fertility evidence from Romania", Journal of Human Resources, vol. 45, no 4, p. 971-997.

RINDFUSS Ronald R., MORGAN S. Philip, OFFUTT Kate, 1996, Education and the changing age pattern of American fertility: 1963-1989. Demography, vol. 33, no 3, p. 277-290.

SATHAR Zeba Ayesha, 1984, “Does female education affect fertility behaviour in Pakistan?”, The Pakistan Development Review, p. 573-590.

SHAPIRO David, 2012, “Women's education and fertility transition in sub-Saharan Africa”, Vienna Yearbook of Population Research, vol. 10, p. 9-30.

SINGH Susheela, CASTERLINE John, 1985, The socio-economic determinants of fertility.

SOLOW Robert M, 1956, "A contribution to the theory of economic growth", The quarterly journal of economics, vol. 70, no 1, p. 65-94.

TOWNSEND Robert M., 1994, "Risk and insurance in village India”, ECONOMETRICA-EVANSTON ILL-, vol. 62, p. 539-539.

WANG Peiming, COCKBURN lain M., PUTERMAN Martin L, 1998, “Analysis of patent data-a mixed-Poissonregression-model approach". Journal of Business \& Economic Statistics, 1998, vol. 16, no 1, p. 27-41.

WOOLDRIDGE Jeffrey M, 2013, Introductory econometrics: a modern approach, 5th international edition. Southwestern Cengage Learning, Mason (Ohio, US), 2013, vol. 183, p. 224-225. 